\title{
Comparative analysis of outreach work with street children in Latvia, Czech Republic and India
}

\author{
M. Lotko ${ }^{1}$, L. Leikuma ${ }^{2}$, and M. Gopalswamy Battle ${ }^{3}$ \\ ${ }^{1}$ Rīga Stradinš̌ University, Riga, Latvia \\ ${ }^{2}$ Riga Social Service, Pardaugavas district division, Riga, Latvia \\ ${ }^{3}$ Tata Institute of Social Sciences, Mumbai, India
}

\begin{abstract}
Based on available statistics, the number of street children is increasing not only in Europe but also around the world. Street children in the world now number 700 million children who are living below the poverty line, which is attributable to income. In the U.S. street children numbers range from a million to two million $-82 \%$ of these children are involved in the drug trade. Number of street children in Latin America is steadily increasing too per year, and approximately 12,500 street children are working [16].

India purportedly has one of the highest concentrations of street children in the world, with UNICEF estimating their numbers to be as high as 11 million [9].

To find out the true numbers and to investigate what was involved in street children's lives, outreach work experiences in Latvia, Czech Republic and India collected statistical data, summarized studies and conducted qualitative research. The qualitative research was conducted in Latvia, India and Czech Republic. In Czech Republic 5 outreach social workers in Hradec Kralove city were interviewed and in Riga 2 social workers who work in different Day Centres were interviewed and asked for their opinion. In India qualitative information about outreach work with street children was conducted together with identified outreach work programs.
\end{abstract}

Key words: Outreach work programs, runaways, social work, social problems, street children.

\section{Introduction}

It is estimated that around 40 per cent of India's children are vulnerable to or experiencing difficult circumstances - such as children without family support, children forced into labour, abused/trafficked children, children in streets, vulnerable children, children affected by substance abuse, by armed conflict/civil unrest/natural calamity etc., as well as children, who due to circumstances come into engagement with the police force. The Constitution of India, the National Policy for Children (NPC) 1974, National Plan of Action for Children (NPAC) 2005 and various child specific and related legislations, attempt to honour a robust commitment to produce a protective environment in India, to ensure every child's right to survival, development and participation. It becomes clearly evident and apparent that children are not homogenous categories. Mapping specific deprivations and addressing the issues facing children, marginalized differently, it is emphasised to develop inclusive approaches related to education, health and protection through diverse interventions [9]. 
Every year on the $12^{\text {th }}$ of April the "day of street children" is recognised. This is a day when the problems of street children are highlighted and explained. The challenges which face them are shown and focussed on.

The children, having problems in the family or problems in the formal and/or informal systems, find an alternative - "the street environment". The child's presence in streets, however, cannot be viewed as voluntary. In many circumstances violence, substance abuse in the family, bullying at school, parental apathy and neglect are factors that contribute.

\section{Definition of street children}

Taking into account institutions that work with street children in various countries, it should be mentioned that national regulatory legislation and various institutions can expand or narrow the definition "street children". The definition however still lacks a common understanding.

The Convention on the Rights of the Child asserts that "States Parties recognize the right of every child to a standard of living adequate for the child's physical, mental, spiritual, moral and social development" (Article 27) [26].

In the United Nations "Street Children Report" - definition "Street children" is based on NGOs and researchers' conclusions and "Street children" are characterized as children below 18; males or females; who spend all or most of their time in streets; who maintain minimal contact with their families or have no contact at all; lack of supervision, protection or guidance, which makes them vulnerable to a wide range of health and psychological hazards [27].

UNICEF has defined three types of street children.

- Street living children - children who have run away from their families and live alone in streets.

- Street working children - children who spend most of their time in streets, fending for themselves, but returning home on a regular basis.

- Children from street families - children who live in streets with their families [28].

\section{Research}

To investigate further outreach work experiences in Latvia, Czech Republic and India statistical data was collected, studies summarized and qualitative research conducted. The object of the study was to make a comparative analysis of the outreach work programs in Latvia, Czech Republic and India. The qualitative research was held in Latvia and Czech Republic. In Czech Republic 5 outreach social workers in Hradec Kralove city were interviewed and in Riga 2 social workers who work in different Day Centres were interviewed. The field work was carried out during the period of March - May 2013. In India, information was collected about outreach work with street children by use of identified outreach work programs and other services provided for street children.

The phenomenon of Street Children has been documented as far back as 1848, when Lord Ashley recorded more than 30,000 "naked, filthy, roaming lawless and deserted children", in and around London [29].

The first shifting paradigm of street children appeared from early 1800 s to the early twentieth century. In the United States this time is generally referred as the "child savers" movement. Before the late nineteenth century, aid to street children in the US was based on religion and funded through the private philanthropy of only a few people. A "child savers" 
movement in both the US and UK paid attention to working poor children in industrial cities [p.27.-29.;8].

In tsarist Russia, the seventeenth-century sources describe destitute youths roaming the streets, and the phenomena survived every attempt at eradication thereafter. Long before the Russian Revolution, the term bezprizornye was widely recognised.

By summer's end in 1917, a Provisional Government ministry in Russia noted the presence in Petrograd of 5,000 children without parents and absolutely homeless. According to the estimates of the city there were about 150,000 children who were partly destitute, their fathers being in the army and their mothers at work.

From 1918 through to 1920 families continued to disintegrate under the assault of combat, flight, hunger, and diseases, casting adrift still more children. American Red Cross in the southern Russia vicinity told of 1,000,000 Russian children separated from their parents and needing food and clothing [p.1.-4.,16;1].

In Latvia, describing street children, the attention has been focused on the problem of illiteracy (the inability to read and write). In 1913 study of 100 children who were under the age of 10 years $-78 \%$ could not read or write, but in 1919 - the figure was $75 \%$.

In the 1920's in Latvia $151.883(60.14 \%)$ children did not attend school, $1925-66.532$ (30.72\%), 1930 - 34.217 (20.71\%), 1935 - 36.739 (16.30\%).

Latvia joined the Children's Aid Union, which was founded in Geneva, opened a branch in Latvia, where leaders from organizations such as Women's Aid Corps, Red Cross, Inner Mission, etc., took part.

In 1928 the Baltic Child Protection Office [30] was appointed.

Outreach work developed in Europe immediately after World War II. In Western European countries the organizations were planning their work - in the UK it is listed as "Detached Youth Work," in the Netherlands - "Street Corner Work", in Switzerland as a "Gassenarbeit", outreach workers in France are called "travailleurs de la Rue", in Germany this approach is mentioned as an outreach work as well as a mobile youth work, in the Czech Republic, terms such as "Streetwork", "terénní SOCIALNO práce", "kontaktní práce", "nízkoprahové center nízkoprahové kluby are used [17].

Major studies in Latvia concerning the problems of street children were conducted in 2002 and 2007 In 2002 I. Lukašinska conducted a study "Street Children in Latvia: problems and solutions" and in 2007 the research "Street children in Latvia: situation and proposals for its improvement" were carried out. Both studies examined the definition of street children, described the rights of the child protective legislation, and highlighted the factors which contribute to street children becoming street children and problems which this target group faces.

In Latvia the street children phenomenon appeared during the period of transition to a free market economy, during the time when families and children were exposed to various types of risks (unemployment, low wages, high public utility payments etc.), but did not receive sufficient support to overcome them. As a consequence, in the mid 1990-s, begging, working and vagrant children appeared in the streets of Latvia's cities. At the same time, children who did not attend school also became a problem [30].

In the Czech Republic outreach work takes in a significant historical development - since World War II methods and approaches were developed for dealing with street children, to gain practical knowledge and workplace experience. Latvian and Czech Republic historical development and experiences are similar, but in the Czech Republic this work with street children has been done for much longer than in Latvia.

In the U.S. outreach work as a professional activity developed in the 1950s where they targeted working with street children - criminals. After the Second World War, this 
problem had received increasing attention. It was set up in the state funded organization that attracted street youth day-care centres, youth clubs. A “youth worker" program was designed [p.85;8].

In India, street children were contextually identified in the early sixties and their number since then has always been estimated to be increasing exponentially. Food, shelter, and safety are highlighted as street children's everyday problems. Besides, often one reads reports of various Non-Government Organisations (NGOs), about how these children face the risk of abuse and discrimination by others. Interestingly, some reports also highlight street children's resilience in their struggle for survival.

Rane and Shroff (1994) in their study "Street Children in India: Emerging Need for Social Work Intervention" attempted to present a profile of street children in India together with reviewing the intervention strategies and existing programs developed by NGOs to work with street children. Additionally, it emphasises the role of institutions of Social Work in evolving systematic modules of training for personnel working with street children. In their study, they found that approximately 314,700 street children were present in six cities, namely Bombay (Now Mumbai), Calcutta, Madras, Kanpur, Hyderabad, Bangalore. D’Souza et al. (2002) in their study "A Demographic Profile of Street Children in Mumbai" attempted to document the "street child" phenomenon, which covered about 1,359 street children.

Rane and Shroff (1994) noted that a substantial number of street children in Mumbai are Muslims. Of the Hindus, almost half belong to SC/ST category. They found that majority of the children came from low socioeconomic backgrounds with family income of less than Rs. $600 /-$ per month. They concluded that poverty and nature of employment, unsatisfactory home conditions and unhappy relationships with family as the main causes for children landing on the streets [9].

D'Souza et al. (2002) found that in Calcutta and Hyderabad there are more children in the age group of 6-10 years in streets; while in Bombay (Now Mumbai) and Bangalore the 11-15 age group figure is high ( $40 \%$ and $80 \%$ respectively). Out of every ten street children in India, eight were found to be Hindus. Christians and Muslims comprise a negligible proportion of the total street children. Only the cities of Madras and Bangalore have street children from Christian communities, while street children belonging to the Muslim community are in substantial numbers in Bombay (Now Mumbai), Calcutta and Kanpur [9].

Further, D'Souza's (2002) study revealed that most of the street boys (approximately $34 \%$ ) have spent more than five years (5-10 years, $M=7$ years) in streets of Mumbai and only a few have spent less than three months in streets. This meant that the street life grows with the children and after a certain period, they find it very difficult to give it up. It becomes a "culture", a "lifestyle"; one that defines them and becomes a part of their identity.

D'Souza et al. (2004) pointed out that nearly $91 \%$ of the girls and $78 \%$ of the boys were exposed to some formal education but their findings were silent on their education level. Among those who had no exposure to formal education, street boys topped the category with $38 \%$. Of the 227 out of 571 respondents who shared that they worked, a majority was the street boys (105/129), and more than half of them (56.39\%) worked as daily wage earners.

"Surviving the Streets" (2011), a comprehensive census of Delhi's Street Children, found that $27.91 \%$ of the street children are "street-living children" who have run away from their families and live alone in streets. Another $29.05 \%$ are 'street-working children', who spend most of their time in streets fending for themselves, but return home on a regular basis. The rest, i.e. $36.03 \%$, are those from 'street families' who live in street with their families. The study found that nearly $1 \%$ of the total number of children in Delhi $(50,923)$ live and work in streets. Further, $61 \%$ of the children surveyed were as young as between 7-14 years of age and $50 \%$ were migrants. The study reported that almost 50\% migrant children in Delhi did 
not want to go back to their place of origin. Reasons for being on the street, predominantly included poverty and hunger (34\%), and search for employment (30\%) either on their own initiative or sent by their parents. Another $9 \%$ of children had run away for various reasons, including curiosity, natural calamities or losing contact with parents while travelling. Only $4 \%$ children slept in shelters while $46 \%$ slept in open spaces, whether with parents, siblings or relatives. About $87 \%$ had to pay to access toilet facilities. The study reveals that almost $50 \%$ of the children were not literate and almost all of them had experienced verbal abuse. About $13 \%$ of children reported that they had seen some child undergoing some form of abuse or other in the street and $67.3 \%$ of children felt they were in danger in streets. Almost $22 \%$ of children reported being dependent on some form of substance, of which nearly $50 \%$ were daily consumers.

A census study in 2012-13 was conducted on Street Children in Mumbai to add knowledge and contribute to form strong developmental policies and services for street children for the city and in the country as whole. The present policies have failed to give the expected results and street children are becoming more vulnerable. In this study in Mumbai itself all together 37,059 street children were counted, while the number could be more, but there could be a number of reasons behind it. With increased surveillance of the city, especially post the 26/11 terror attacks, it has been increasingly difficult for the homeless population to live in public spaces and the child street activists may have been forced to shift to the nearby location of the city limits.

\section{Results}

\section{Outreach work in Latvia}

In Latvia in 1997 a project "A child on the street" was carried out, which was realised by Social Work and Social Pedagogic higher school "Attīstība" and Criminological Research Centre assert that "in the 20th century 20th-30th years, special attention has been focused on children who were left in street with no maintenance and do not attend school. These children were added to the orphans that in our days would be defined as "a child in the street." Street children's problems have been addressed through the education system alignment. Already in 1919 particular attention was paid to the economic, social and educational sphere [30].

More organizations worked with outreach work - one of which was Association "Street Children". Association "Street Children" history dates back to 1998, in the framework of the Soros Foundation - Latvia (SFL) and the Royal Bodušna Foundation (KBF) Street Children program and street children NGOs Network.

The goal of Association "Street Children" was to help member organisations professionally and effectively solve the problems of street children, providing legal support for the promotion of children's rights protection, the development of social work practice and public awareness in this area. Recent data on the Association "Street Children" activities are available only for 2004 and The "Street Children" disbanded in 2008 [20].

In 1999 NGOs were involved in the network of 28 non-governmental organizations from different Latvian regions, 14 of which signed contracts with the SFL, which was a commitment to work together towards a common goal - to provide assistance to street children so that they can be fully reintegrated into society with equal opportunities as other children have. The NGO network was open to all organizations that wanted to participate in network activities and to contribute to solving the problems of street children [13]. 
Activities carried out by the NGO:

- Seminar "Public resources in solving street children problems";

- The survey on number of street children, their families and their social background, as well as the nature of the NGOs that worked with street children, organisation and implementation;

- Foundation of Association for Street Children, in order to obtain a network of independent legal personality;

- Website development [13].

Also were taken measures such as:

- Development of day care centres and overnight shelters (e.g. "Diaconate centre", "Day centre for street children", NGO "Cerība bērniem" (Hope for children),' the Salvation Army shelter, NGOs orphan care centre "Together with us", Latvian Orthodox Churches Sat. Nicholas Riga Christian children's shelter etc.);

- Children's free time by organizing camps, sports clubs, cafes, hobby groups (e.g. "White' Sparrow", etc.);

- Psychological help for street children ("Psychological crisis support centre" in Daugavpils", crisis" centre "Skalbes", Talsu crisis centre, etc.);

- Child protection specialists and teachers training (e.g. "Centre against violence for children and family support", "Latvian children's cultural Support Fund", "Social Education Support Fund", etc.) [13];

- NGO "Dialogue" - proposed rehabilitation program whose aim was to acquire the skills to live and solve problems without substance abuse, to learn life and work skills, reintegration into the family and society, to be able to live independently [14];

- Children Rights Protection Inspectorate - counselling and psychological support for children in crisis situations. In 2012 a free of charge psychological support to foster families, guardians, adoptive parents, host families and the children and families in crisis situations was provided [15].

- In 2010 in Latvia an SEB bank Mentor program was implemented - in the project the movement against youth drug abuse was developed, the project provides young people with additional adult support, care and understanding. The project is ongoing support from SEB bank, as well as close cooperation with the International Mentor and Mentor Sweden [21].

In Riga outreach work is carried out by Riga Addiction Prevention Centre outreach work professionals - social workers, social pedagogues and psychologists specifically trained to work with the target group - drug users, their families and children at risk, establishing and maintaining contacts with them [25].

\section{Outreach work in Czech Republic}

In the Czech Republic the most common age for street children is between 10-18 years, but most street children fall in the group of 14 to 18 years. Most often street children can be found in urban areas where children have anonymity and they do not obey social norms - they are out of control of any systems [10].

In the study of reasons why children are on the street, in the Czech Republic the following data was found: children are victims of sexual abuse in the family, relatives, schoolmates, friends (40\% of cases), children avoid their parents (25\%); addiction: drug and alcohol abuse in family (15\%), these are foreigners who are looking for better fortunes in the Czech 
Republic (20\%). These are the Roma people and families from neighbouring Slovakia or Vietnam, who are engaged in trade [10].

The study also shows other reasons why the child is on the street: lack of space at home, no parents, hatred of one or both parents, lack of understanding from the parents; the child's parents do not accept sexual orientation, poverty, mental disorders, etc. [18].

Both in Latvia and the Czech Republic, the majority of street children come from dysfunctional families or orphanages.

Not only in Latvia, but also the Children rights Committee in the Czech Republic concern has been expressed about increasing number of children living in streets, they are vulnerable to sexual abuse, violence - including police violence against children, they have no access to education, increase in dependency on substance use among the young, sexually transmitted diseases, HIV/AIDS and malnutrition. The Committee notes that the main response to this situation is institutionalization [5].

It has been established that in the Czech Republic there are about 90 organizations that deal with issues affecting street children and 55 outreach programs have been realised [11].

\section{The Czech Republic government's policy concerning street children:}

- Children's Rights Law, adopted in 1991;

- The problem of street children is also under the Ministry of Labour and Social Affairs competence (there are regional offices where social workers are trained on the specifics of the problem work);

- Work with children and young people in offices and clubs to motivate young people, preparing them for education and other programs, which help them quickly get a job so that the possibility of a young person getting back on the street could be reduced;

- Developed health care system, and paediatric clinics;

- Making multi-education available in the schools: (education consultant, psychologist), psychological services centre (advice for parents on children's issues and training on how to handle crisis situations);

- Special education workshops (psychological counselling for children under the age of 15 or 15-18 years, boys and girls living alone);

- Children's homes (providing care and shelter);

- Correctional centre (for children aged 15-18, who have been convicted for criminal activity. Alternative could be a youth community service, which would be more effective as a closed re-education institution.) [10].

Organizations and activities that are carried out in the street to work with street children in the Czech Republic:

- The "Opportunity" ("Šance") - established in 1995. The aim of the Association is to systematically and professionally help children and young people who, for various reasons, find themselves on the street. Association activities: daily life in the centre "Streetcentrum" and on the streets, improve and enhance children's knowledge of public relations, organizes charity events aimed at improving the living conditions of the target group and gradually integrate them into society; a public correction is made.

- The organization "Bliss without Risk" ("Rozkoš bez rizika") - focused on HIV and AIDS prevention activities for people who provide sexual services.

- Centre for the prevention and treatment of drug "DROPIN".

- "Czech Outreach Association" ("Česká associations Streetwork”).

- Safety line - a civic association which was founded in 2004. Helps children, youth and adults in crisis situations. Hotline operates 24 hours a day (up to 2,000 customers a day). 
- "Safety Red Circle" ("Bílý kruh bezpečíi”) - since 1991 providing free assistance to victims of crime and witnesses to crime, it is a moral and emotional support to violencerelated cases. Operates six hospitals.

- Children's crisis centres - operating since 1992 by provision of long-term specialist care, legal advice and medical assistance.

- Fund "Our children" ("Nase dítě") - takes care of vulnerable children who are in difficult living situations, direct financial aid and educational events.

- The half-way house - after leaving orphanage home for one year provides the child with accommodation, teaching independent living skills.

- Project "We were street children" ("Byli Jsme Děti Ulice") - are organized a variety of events and educational activities, the opportunity to attend public and private events and holiday camps, where former street children and drug addicts share their experience.

All of the above mentioned institutions, organizations and projects are directly aimed at outreach work in the Czech Republic. Work in this area does not stop, but continues to evolve rapidly.

In the summer of 2012 an inner-city mechanism project for young people aged 15-22 was implemented. The project's mission is - “... to be available to the young in their need/necessity.” It was created as a safe and reliable place for teenagers in Karvina, Moravian - Silesian region, located in the Czech Republic [12].

\section{Outreach work in India}

In India about 190 organizations are working with street children and 32 organizations offering different type of services to the street children. In Mumbai itself 47 organizations are operating. They are still not being able to make out every single street child due to highly increasing number of street children [19].

Many organizations have service Contact points at the most convenient sites for children newly arrived at the station to get in touch with the organizations. These points are run as day-care centres for working children. These three contact points -

1) GRP Centre, all major railway Stations in metro cities as well as big towns.

2) Platform Centre, Railway Station, and Bus stand

3) Religious places/worship [2].

The presence of an outreach worker at entry points like main railway stations or bus stand can sometimes be very crucial in terms of prevention. Children entering the city are immediately located either by the police, ticket collectors and outreach workers or other children. Many times it helps them to come into contact with the agency social worker before any anti-social elements take charge of their lives. In a few cases, if a child is willing, the agency is able to locate the parents of the child and family reunion is possible within the short time after his/her arrival in the city.

Many Faith based organisations have embarked on their own project for street children or they assist other organisations who are working for street children, one of the best and easy outreach programs in India as many of the temples, mosque and churches offer free meals to poor people on a daily basis. Most faith based organizations claim that they engage in secular activities as far as service delivery is concerned. And many children visit during meal times either they receive contact with a religious Priest or the organizing professionals identify such children and subsequently talk to them and either they are reunited with their families or referred to organizations. Many FBO has an integrated program for street children. A professional social worker is employed for service delivery [23]. 
A Contact Centre is a place close to the child's place of stay or work, where a child can drop in for a few hours to be with the caring adult, utilize certain facilities and to participate in the ongoing educational, recreational and developmental programs like dance, drama, music and interactions through group activities. These centres do provide them with few facilities like bathing, lockers and meals and look after their overall development by providing nonformal education, support to complete formal education, developmental and vocational skill, as well as educate them on hygiene, child rights, addiction etc. Parents' meetings involve them in child development programs.

Most of the agencies provide shelter/home separately for girls and boys, with facilities of providing formal, non-formal education, developmental programs and skill based programs, putting emphasis on their overall development by organization of various sessions for the children, and individual and group counselling are an integral part of the shelter home [4].

In night shelter, the children can use the facilities to bathe, wash clothes and keep their belongings in a locker. They also get a meal and some play material, counselling etc.

In day care centres, children are offered vocational training opportunities, formal, nonformal education. Some agencies have a saving scheme for the children. They can deposit and withdraw money every day. The social worker at the centre can then get a chance to interact and intervene in their lives and suggest other options for the life.

DROP-IN-SHELTER: This is a 24-hour drop-in-shelter for older street and working children. Most of the children in the target group work for their livelihood, so they need more freedom to come and go at will. Accordingly, any boy can drop in at any time to take a shower, wash his clothes, eat or rest. In addition, the centre offers special counselling, vocational training and assistance in job placement [2].

Community based outreach programs: An outreach program in slums aims at preventing young residents of the area from becoming street children. A major component of the outreach is education, both formal \& remedial.

Mobile School: The concept of a mobile school or school on wheels is used to conduct non-formal education classes in locations where there is no space to sit for such activities. In addition, there is distribution of the day meal, vocational and small business training, organising the recreational activity camps and outing etc. [22].

Many city organisations have expanded their focus from urban child protection to rural livelihood development. Years of experience and interaction with children on the streets has shown that majority of them have migrated from rural areas. In order to prevent children from migrating to cities and live under appalling conditions on the streets without any opportunities for education, growth and development, these organizations initiated a rural development program in different districts. Each organisation has their own way of outreach strategies, but they all have emphasis on enhancing the quality of education in rural areas and improve the quality of life for the community by developing work opportunities in the rural areas [4].

CHILDLINE is a 24-hour national emergency free telephone service for children in crisis. The telephone number 1098 is operational in all 83 cities in India. There are a total of 163 CHILDLINE collaborative and support organisations all over the country, which work for the noble cause of CHILDLINE service.

The Mumbai child line call centres receive about 150 to 200 telephone calls daily. The timely intervention of CHILDLINE has saved life of quite a number of street children in and around.

Conducting outreach is the basic work of CHILDLINE, by which the information of CHILDLINE is spread to the children, community as well as to the public from place to place and person to person. The team members and the children get a good contact through 
the outreach. The responses after the outreaches are good and more people are now aware of the CHILDLINE. Awareness of CHILDLINE is spread through street plays, puppet shows and direct intervention with children, community and public.

The CHILDLINE call centre receives nearly 150 to 200 calls daily. Along with the Centre Coordinator there are 09 team members to run this project. This new project also paved way for 5 of our ex-beneficiaries to get a job opportunity as a team member for the CHILDLINE Collaborative Organization [24].

\section{Conclusions}

In the Czech Republic, Latvia and India causes of children getting on streets are common, e.g., family life situation deterioration, inadequate education and value system of the family, low social status, poverty, rising unemployment, conflict in the family - divorce, child abuse and violence, lack of emotional ties with parents, educational problems, conflicts at school, friends unfavourable impact of interest and unawareness of their own identity problems.

In Latvia, Czech Republic and India operate non-governmental organizations, crises and day-care centres that address the street children problem. For solving addiction problems in Latvia and Czech Republic rehabilitation centres are available.

Latvian congregation also participates in the creation of street children's activities, in the Czech Republic it occurs less. In India there are many faith based institutions working.

The Czech Republic's street children problem is institutionalized. The Czech Republic has developed programs and trained street social workers to identify places where children gather in streets, as well as how to recognize their own children - in Latvia this practice has not been implemented yet. In India there are contact points where professionals go to search for children on the street.

In Czech Republic non-governmental organisations annually make activities such as camps for street children, and all information is published on the websites of organisations that allow easy access to information for all members of society.

Outreach work practice in Latvia and Czech Republic is similar. There are signs that work with street children vary. In order to better identify places where street children gather, as well as to develop outreach work, this practice needs to be developed in Latvia. Also in the Czech Republic the street children are attracted to the institution with the help of local radio advertising, newspapers, information materials and social sites. In Czech Republic social work with a client case file is created electronically and data is available also to the client.

In Latvia, India and Czech Republic in outreach work practice various channels are used to identify street children, such as collaboration with the school social pedagogues, police, family doctors, through day centres and going out in the streets, etc.

In Latvia and Czech Republic specific criteria by which it would be possible to determine the status of street children have not been identified, but there are criteria based on which the problem of the street children, such as school absenteeism, ramble etc. can be identified.

In India poverty emerged as the main backdrop through all the studies. Whether through the census or the survey data, one could relate poverty with most of the findings of the study. Most children lived with their families or were in touch with them; they were on the street as their families were on the streets, or they had been pushed out from their families due to poverty. Most children had to work to subsist, while they should have been in school. Many had to drop out of school in order to work or had to earn and go to school, thus negatively affecting their chances of continuing their education. A significantly higher number of children had to often miss meals, and many of them were pulled into addictive behaviour. 


\section{References}

\section{Literature}

[1] Alan M. Ball "And Now My Soul Is Hardened: Abandoned Children in Soviet Russia 1918-1930” University of California Press, 1996.

[2] Annual Reports, 2005-06, Salam Balak Trust Mumbai.

[3] Annual Reports, 2010-11, Vatsalya Trust Mumbai.

[4] Annual Reports, 2011-12, Vatsalya Trust Mumbai.

[5] Committee on the Rights of the Child, Czech Republic 2003.

[6] Dabir, Rebuilding Lives of street Children, A study of street organizations in Mumbai and role of Faith and Religion in service delivery. September 2005.

[7] Defending Children's rights in Europe (A Practical Guide) Spain 2011.

[8] Gibson Kristina E. "Street Kids: Homeless Youth, Outreach, and Policing New York's Streets" New York University Press, 2011.

[9] Tata Institute of Social Sciences, Making street Children Matter, census study in Mumbai City Mumbai and Action Aid, December 2013.

[10] Hudečková, L. "Děti ulice" Masarykova Univeraita v Breně, 2007.

[11] “Ielas bērni Latvijā" SIA “AC Konsultācijas” Latvija, 2007.

\section{Internet resources}

[12] A Gape Adventures/youth work in Czech Republic; www .agapeadventures.ie

[13] "Asociācija ielas bērniem"; http://www.inarchive.com/lv/i/ielasberni.lv/ 335/2011-02-05-description/2/Ielas_Berni/

[14] Atbalsta centrs visiem, kurus skar HIV/ AIDS; Dialogs; www . diacentrs. Iv

[15] Bērnu tiesību aizsardzības inspekcija; www.bti.gov. Iv

[16] Consortium for street children; Street children statistic; www.streetchildren. org.uk

[17] Česká asociace streetwork; http://www.streetwork.cz

[18] Děti v ohrožení; Rasismus// Jeden svět na školach 2006; www . jedensvetnaskolach. cz

[19] List of the organizations working with street Children in India: www . karmayog. org

[20] Lursoft - Uzņēmumu datu bāzes; http: //company . lursoft. lv/ielas_berniem? lang $=1 \mathrm{v}$

[21] Mentor Foundation; www .mentorfoundation.org

[22] Outreach programs ww. doorstepschool.org

[23] Outreach programs ww. hinduism.about.com

[24] Outreach programs ww. hamarafoundation.com

[25] Riga City Council Welfare Department; www .narcomania.Iv

[26] http://www.ohchr.org/en/professionalinterest/pages/crc.aspx

[27] http://www.unodc.org/pdf/youthnet/egypt_street_children_report.pdf

[28] http://schoolsonline.britishcouncil.org/street-children

[29] http://www.dwellingplaces.org/index.php/faqs/106-faqs-street -children

[30] http://providus.lv/article_files/1464/original/BernsUzIelas.pdf? 1331650348 